\title{
Slovenia: At a Distance from a Perfect Religious Market
}

\author{
SERGEJ FLERE
}

\section{Introduction}

Slovenia is surrounded by predominantly Catholic countries and is also "historically Catholic'. During modern times, the Catholic prevalence in Slovenia has somewhat diminished, but Slovenia can hardly be called confessionally pluralist, since other religious groups (mainly Lutherans) are very small. During most of the twentieth century Slovenia formed part of Yugoslavia, a multinational and multiconfessional state. After the Second World War, as a communist state, Yugoslavia was known for a 'soft' political system and a liberal stance towards religion. In fact the earlier period (until 1965) was characterised by a repressive policy towards the major religions. This is partly to be accounted for by the potentially divisive nature of religion in this composite country, and partly by the need for this particular brand of communism to assert its 'authenticity' and 'purity' (Alexander, 1979; Mojzes, 1992). Within Yugoslavia, Slovenia was regarded as the most liberal environment from the religious point of view.

Slovenia acquired independence in 1991 and avoided involvement in the conflicts that subsequently engulfed the rest of Yugoslavia. Since then Slovenia has seen peaceful development, and the economy is doing rather well, Slovenia taking the 29th position in the world according to the Human Development Index (Human 2003). At independence a constitution was adopted and, as in other postcommunist transition countries, it guaranteed the principle of separation of church and state (Article 7 Para.1). The political objective of this principle may be to guarantee freedom of conscience, but its latent social function goes beyond this. Its social and societal function is to create space in which religious views and practices can be freely exercised and can compete in a free environment; or, to put it in contemporary parlance, where religious entrepreneurs have the perfect market possibilities to offer the variety of their services, or 'goods', and to enter into 'exchange' relations with religious consumers, while the latter have the widest opportunity to choose among various 'religious products'. Thus some will choose a strict religion and a correspondingly greater 'return' for a greater (alleged) renunciation of this-worldly goods, albeit a 'return' that is somewhat postponed and comes in the form of a sort of 'compensatory' promissory note. One may choose liberal or restricted religion, ascetic or hedonistic, ritual-rich or ritual-poor, or may combine these elements in the most varied fashions. These types of religion, furthermore, may be combined with a variety of creeds and doctrines as well as with a variety of organisational forms, which call for further choice. This view of religious life (Stark and Finke, 2000) as a specific market that is not substantially different from the commerical market or the marriage market provides a perspective for an understanding and close analysis of certain processes in religious life. 
The main empirical example that can be convincingly and plausibly explained is the difference in levels of religiosity between Western Europe and the USA. In the former, religious life is waning and lax, whereas in the latter it is varied, vital and thriving (Dogan, 1995).

The situation in transition countries is distinctive, since in communist countries religion often served as a niche for social protest and dissent (though the situation differed from country to country and varied over time and even within one country). Nevertheless, the processes of 'religious renewal', 'rechristianisation' and 'evangelisation', which were heralded in the early $1990 \mathrm{~s}$, and which really began at that time, turned out to be of short duration. (The question of course arises as to whether those processes would really have contributed to a transition from communism in the context of modernisation.)

As noted above, the Constitution of Slovenia provides for strict and full separation of church and state, and such separation should be the basis for liberty, for an absence of oppression and for pluralist democracy, in particular, of course, in the sphere of world-views and religion. The formation of a market without legal, political and administrative impediments and limitations is the social texture within which the development of such a pluralist society would take place. I shall indicate certain areas where conditions for stimulating this kind of development in Slovenia have been met, and certain areas where there are still indications of a rather imperfect market and of limitations on the growth of variety in offerings and consumption.

\section{Steps Towards an Improved Market}

The major steps towards an improved religious market in Slovenia since 1991 are as follows.

Legislation has been introduced to prohibit denominational/confessional activity in elementary and secondary education. In Slovenian circumstances the absence of a provision of this kind would allow the majority religious denomination to consolidate its predominance and display its ideological hegemony. There is no religious instruction in the public education system and this ought to mean that no religion receives privileged treatment. As is usually the case, education is an area of particularly intense ideological battle and the exclusion of religious instruction, although a logical consequence of constitutional provisions, was not achieved without opposition, which continues. Many political actors have taken part in this ideological battle and one cannot be confident that the solution will be a lasting one.

The practice of arranging a Catholic blessing of official premises (schools, public offices), which happened on a number of occasions in the early 1990s, was subsequently denounced in the media and by liberal public opinion, and now appears to have ceased.

In 1993 the government established an Office for Religious Communities (Urad $\mathrm{za}$ Verske Skupnosti) at sub-ministry level. Its powers are very limited and nothing like those of a classical ministry for religious affairs. It is meant to be a forum for dialogue and for the resolution of technical issues such as the tax position of religious communities. The registration of religious groups is also part of its brief. This is meant to be a technical matter (according, in fact, to a law dating from communist times ${ }^{1}$ ), but the Office has recently been the subject of sharp criticism for exceeding its constitutional brief: it has withheld registration from some religious groups. At one time there were nine religious groups that had long been awaiting registration: the Christian Calvary Church (Krščanska Cerkev Kalvarija); the Hindu Religious Community in Slovenia (Hinduistična Verska Skupnost v Sloveniji); the Universal Religious Community of the Rising Sun (Univerzalna Verska Skupnost Vzhajajočega Sonca); Dharmaling - the Congregation for the Preservation 
of the Vajrayana (Dharmaling - Vadžrajana Budistična Kongregacija); the Ljubljana Christian Center (Krščanski Center Ljubljana); the Raelian Society of Slovenia (Raeljansko Društvo Slovenije); the Ljubljana Christian Community (Ljubljanska Krščnska Skupnost); the Ultra Telema Holy Church (Sveta Cerkev Ultra Teleme); and the International Church of Christ (Mednarodna Kristusova Cerkev). The last four are still awaiting registration; the others have now achieved registration, in part as a result of public pressure. The total number of registered religious communities in Slovenia is now 36. The reason for the postponed registration is to be found not in the fact that there are any substantial impediments to registration, as these are almost nonexistent according to the 1976 law, but in the fact that the Office was allegedly unclear as to which administrative procedures should be applied (Gedrih, 2003), despite the fact that administrative procedural laws and practices based on them have been in place for over 70 years. Other shortcomings on the part of the Office are also alleged (for example, not assisting religious communities in resolving their legal problems, and organising public discussion orchestrated to favour the majority church (discussed below)), and the cumulative impression is that this administrative agency is less interested in promoting human rights in the area of spirituality and religion than in promoting the privileges of the dominant group.

There has been no change in legislation regarding the founding of religious institutions; the above-mentioned relevant legislation, which is still in place from communist times, is basically liberal and non-discriminatory in this respect. ${ }^{2}$

\section{Factors Obstructing the Development of an Improved Market}

The Slovenian political and cultural landscape is such as to make it unlikely that the constitutional principle of separation of church and state would be implemented in a neutral, mechanical and complete manner. Slovenian history follows the 'Latin pattern' (Martin, 1978) of a political and cultural environment characterised by a dominant Catholicism and an opposing anticlerical liberalism, without other major players. On the face of it it might seem that with the constitutional provision on church-state separation and the legislation on school curricula the anticlerical forces have definitely prevailed in Slovenia. This would be a premature conclusion, however, and we should note a number of facts and events that are indicative of a continuation of Catholic hegemony.

First, Catholic prelates are inclined to speak in tones of conservative arrogance. A few quotations will illustrate. 'Through the church the Slovenian nation has been, for 1250 years, a component part of Europe. Today the church remains the stable foundation of our spiritual anchorage in the European cultural tradition. To a great extent, Slovenian political life has yet to achieve this' (Gril, 2000, p. 3). 'Christ is the only and eternal standard of any culture' (Štuhec et al., 2002, p. 22). 'We need to change our historical recollection .... In this respect, almost everything needs to be changed... fundamentally ... from Trubar to Prešeren to Cankar, up to the present day' (Rode, 1993, p. 120). ' 'To live for God or to live for death. There is no third way.' (Rode, 1997, p. 46). 'What can a young Slovenian without a Christian education comprehend when he visits European museums, gazing like an idiot, which he in fact is?' (Rode, quoted in Žerdin, 1999 , p. 6). 'For an impenitent unbeliever there is and can be no mercy' (Perko, 1999, p. 4). 'The major problem of those who invoke Christ but reject the institution of the church is their personal integrity' (Krašovec, 1996, p. 9). These and similar vehement and rapturous statements by church prelates inflame the Slovenian public scene and political and cultural life, enlarging the gap between those favouring a public role for the church in all dimensions and the rest. ${ }^{4}$ The imputation by prominent church personalities is that Christianity is possible only by way of Catholicism, that Catholicism is possible only 
by the institutional way and that the institutional way may pass only by way of authority; furthermore that Slovenia is lagging behind 'her church' and that only the latter can show the 'true way', which is to be found in a (vaguely-defined) tradition of church hegemony. The main concrete objective, as yet unachieved, is religious instruction in public schools. Archbishop Rode of Ljubljana has gone so far as to claim publicly that people educated without religious instruction are like 'German sheepdogs' (Žerdin, 1999) (meaning that they display unthinking and uncritical obedience).

The church's stance has brought about a distancing of many Catholic believers from their church. During the 1990s there has been a growing division between those favouring a political role for the Catholic Church and those opposed to this. The former have lost ground. Though the number of those in full agreement with the proposition that 'church prelates should attempt to influence people's electoral choices' rose during the 1990s from 5.6 per cent to 12.9 per cent, the number of those disagreeing rose much more, from 25.5 per cent to 61.0 per cent, thus becoming an absolute majority. The number of those holding moderate views or undecided on this issue declined significantly (Flere in Toš et al., 1999, p. 137). Furthermore, according to the Slovenian Public Opinion Survey (Slovensko Javno Mnenje) of 1998, of all those declaring themselves to be believers (64.7 per cent), fewer than two-fifths said they attended Sunday service regularly or frequently (38.7 per cent of those declaring themselves as believers) (Toš, 1999, p. 877). A study of morality also demonstrated that official church positions on sin are predominantly rejected even by believers, as well as by nonbelievers. Believers tend to base their morality directly on the example of Jesus Christ; catechismic morality is empirically linked more to psychological authoritarianism than to religiosity (Flere and Lavrič, 2003). This is a situation typical of a dominant Catholicism, with a split between traditional church members, who are often apathetic and uninterested, and a smaller number of zealots, comprising the higher clergy and militantly conservative groups.

The other major institutional player on the Slovenian scene is the government. The major political party in government in the post-independence period has been the Liberal Democratic Party (Liberalno-Demokratska Stranka - Liberalna Demokracija), verbally committed to liberal principles of freedom of conscience and separation, but usually in coalition with parties favouring other options, like the Slovenian People's Party (Slovenska Ljudska Stranka), with a long pro-church history. The Slovenian government may negotiate at times with a number of churches (besides the Catholic Church, mainly the (Lutheran) Evangelical Church (Evangeličanska Cerkev) and the Serbian Orthodox Church), but only with the Catholic Church are these negotiations carried on in the form of international negotiations, between the Slovenian government and the Holy See. They have resulted in a draft contract between these two. According to Slovenian law an international contract takes legal precedence over acts passed by the national parliament. Thus regardless of the content of an eventual contract the Slovenian state would in fact be limiting its sovereignty with respect to one church only. The Slovenian state might not bind itself to very much expressis verbis, but whenever issues were to arise which were touched on in the contract (were it to come into force), Slovenian sovereignty would be limited and there would be the possibility of legitimate Vatican interference. It is not surprising, then, that the draft contract is considered constitutionally disputable (particularly by the two 'lay' political parties the Liberal Democratic Party and the United List of Social Democrats (Združena Lista Socialnih Demokratov)) and that it has been a matter for consideration by the Constitutional Court. The court found that the draft contract was not incompatible with the Constitution, but determined that it was of restricted application, ruling out the possibility of the Roman Catholic Church's interpreting it as allowing its canon law to function as a system parallel to Slovenian state law (Opinion, 2003). 
Nevertheless, critical observers like Matevž Krivic, a constitutional lawyer, consider that the draft, when adopted, may still serve as an instrument for church interference, particularly if a government 'friendlier' to the Vatican were to come to power (Krivic, 2003, p. 1).

The proposed contract is indicative of the fact that the Slovenian government is not treating all religions in the same manner; it is extending privileges to, or at least guaranteeing the present position of, one church, that church being the historically traditional church of the majority. The Slovenian government subsidises the social security contributions of officials of some churches, primarily of the Roman Catholic Church, but does not do so for all religious groups. The fact that these public funds are disbursed without impartial criteria being applied and without a public procedure was noted as inadmissible in the Slovenian Ombudsman's Report for 2001 (Poročilo, 2001). The government subsidises the maintenance of Catholic buildings while frequently placing obstacles in the way of other groups wishing to construct buildings for religious purposes. There has been a longstanding issue about the building of a mosque in Ljubljana (which now seems to be reaching resolution after a bold municipal decision in December 2003 - see below). The government has introducted state-paid military priests into the armed forces. These priests have thus far been exclusively Catholic. The procedure for their appointment meant that other religious groups were unable to present candidates (although some provision was made for the (Lutheran) Evangelical Church). Some specifically Catholic festivals that are not generally celebrated by all Christian denominations have been declared state holidays. The papal nuncio serves as permanent dean (doyen) of the diplomatic corps. In spite of the fact that the principle of separation of church and state is in effect in the sphere of education, the Roman Catholic Faculty of Theology was reintroduced into the University of Ljubljana in 1992, even though it remains simultaneously under Vatican supervision.

A new draft law on religion, to replace the law of 1976, has been under consideration for some time. The draft envisages the re-registration of already registered religious groups, with the exception of 'religious communities whose centuries-old activity and presence on the territory of the present Republic of Slovenia is a generally known fact ... which do not need to submit minutes of their founding assembly and the conclusions about their establishment' (Article 23 of the draft law, 1998). One may conclude that this is no substantial privilege, since religious activity may be undertaken freely under the Constitution without any registration, but the waiver is indicative of the extending of symbolic privileges. If one takes into account the fact that gaining registration is a precondition for permission to construct religious premises, for social security benefits for clergy, and for property and taxation rights, then it is clear that registration is not in fact just a technicality without any substance.

\section{Conclusion}

The situation in Slovenia is not as it is in some Eastern European countries where Protestant groups are persecuted as foreign, as 'sects' or as harmful to tradiitional family values. Nevertheless one recent event deserves attention. The sociologist of religion Ales Čnic (2003) reported in Delo, the main Slovenian daily, that the Office for Religious Communities had organised a meeting to study religious groups, which had ended in a proposal to classify religious groups in various categories such as 'churches' and 'sects'. Even though this type of classification is common in Eastern Europe it would be out of line with the Slovenian Constitution; indeed, one could even call it an 'attack' on the 
Constitution. The head of the State Office later complained that the meeting's intention and conclusion had been misinterpreted.

The Slovenian situation is one of enduring Catholic hegemony. It is also one of a near-monopoly, but one that is losing its hold. The number of declared Catholics has diminished, ${ }^{4}$ in line with Stark's expectations. Lutheran Evangelicals have definitely gained public stature and there is even a state holiday devoted to the Reformation (Dan Reformacije). New groups are active on the religious stage, although they still remain very marginal. One could say that the Seventh-Day Adventists have attained the position of a 'denomination' (in Niebuhr's definition), or at least that of an established sect, and that the Jehovah's Witnesses and the Baptists may be approaching the position of an established sect. Oriental religions have a minute following, mainly in Ljubljana. Islam is a different matter: the number of Muslims is steadily rising, with a demographically significant growth from 1.5 per cent of the population in 1991 to 2.4 per cent in 2002 (Official Census Data 2002); nevertheless Slovenia is yet to obtain its first mosque, despite the fact that the Islamic community has been trying for decades to obtain permission to build one. Recently the Ljubljana municipal authorities, with a leftist majority, took a major step towards approving the site for construction and allowing a minaret, but rightist parties (the Slovenian Democratic Party (Slovenska Demokratska Stranka) and New Slovenia (Nova Slovenija)) are threatening to organise a city referendum, quoting technical reasons, but in fact exploiting xenophobia.

In the new religious marketplace the Catholic Church has not been strengthened. It is questionable whether it has come to terms with pluralism and secularisation of the Western European kind (and in this respect it seems to resemble the Catholic Church in Poland (Szosztakewicz, 1999)). Possibly it has made some headway in individual psychological counselling. The church is not changing the traditional Catholic product, however: in its marketing strategy it makes no compromises with postmodern attitudes, instead continuing to insist on traditional values, traditional piety and church authority, the church being understood as the only guarantor of Slovenian identity. It seems to expect the rest of Slovenian society and indeed the state to follow its lead, criticising in its newspaper Družina those who do not subscribe to its (often undefined) values. Even if the Catholic Church were to gain the major victory of being allowed to provide religious instruction in the public education system, this would not be an education in tune with the postmodern world.

\section{Notes}

1 The still unrepealed 1976 Slovenian Act on the Legal Status of Religious Communities (Zakon o pravnem položaju verskih skupnosti) does not specify the number of signatories required for an application to register a religious community, whereas the new draft law specifies a minimum of 100 (citizens and permanent residents); the draft sets more restrictive and more detailed conditions, and also envisages fines for violations. I personally know of instances during communist times of one individual successfully registering a religious community. Neither the 1976 law nor the new draft law enters into a definition of 'religion'.

2 The liberalism of registration was a counterbalance to the checked position of the major religious groups, which were limited as far as the possibility of acting outside the spiritual sphere was concerned.

3 Trubar is a Lutheran figure of the Slovenian Enlightenment who standardised the Slovenian language as a vehicle for making the Scriptures accessible to ordinary people; the standardised language naturally proved to be relevant for other purposes too. The latter two are major Slovenian historical literary personalities, both with a pessimistic approach to life.

4 The number of those declaring themselves as Roman Catholics dropped from 71.6 per cent in the 1991 census to 57.8 per cent in the 2002 census, while the number of those who declined to respond to the question rose from 4.2 per cent to 15.7 per cent. 


\section{References}

Alexander, S. (1979) Church and State in Yugoslavia (Cambridge, Cambridge University Press).

Črnič, A. (2003) 'Sekte privlačijo deprivilegirane sloje: cerkve ali sekte?' ('Sects attract underprvileged strata: sects or churches?'), Delo, 11 January, p. 8.

Dogan, M. (1995) 'The decline of religious beliefs in Western Europe', International Social Science Journal, 47, pp. 405-19.

Flere, S. and Lavrič, M. (2003) 'Dejanska in katoliška morala: sociološki vpogledi in preizkusi na Slovenskem' ('Actual morality and Catholic morality: sociological insights and tests in Slovenia'), Družboslovne Razparave, 19, 95-105.

Gedrih, M. (2003) 'Greh zoper verske skupnosti' ('Sin against religious communities'), Delo, 14 August, pp. 1-2.

Gril, S. (2000) 'Naš komentar' ('Our commentary'), Družina, 49.

Human (2003) Human Development Report 2002: Deepening Democracy in a Fragmented World (Oxford, Oxford University Press).

Krašovec, J. (1996) 'Intervju' ('Interview'), Razgledi, 30 October, pp. 2-9.

Krivic, M. (2003) 'Mižanje pred umazanimi triki vlade' ('Closing one's eyes to the government's tricks'), Mladina, 48, p. 1.

Martin, D. (1978) A General Theory of Secularization (Oxford, Blackwell).

Mojzes, P. (1992) Religious Liberty in Eastern Europe before and after the Great Transformation (Boulder, CO, East European Monographs).

Official Census Data (2002), www.stat.si/popis 2002/si/rezultati.

Opinion (2003) Opinion no. 5134 of the Constitutional Court of Republic of Slovenia, 19 November 2003, Uradni list Republike Slovenije (Official Gazette of the Republic of Slovenia), p. 118.

Perko, F. (1999) 'Prebliski' ('Intellectual flashes'), Delo, 22 October.

Poročilo (2001) Poročilo za 2001 Varuha Človekovih Pravic, www.varuh-rs.si/cgi/tekstislo.cgi?porocpub.

Rode, F. (1993) 'Da bi nam srca vnel za Cast dežele' ('Let our hearts be ardent for the honour of the land'), in Kristjanovo Politično Tveganje (The Christian's Political Risk) (Trieste, Društvo Slovenskih Izobražencev).

Rode, F. (1997) 'Intverju' ('Interview'), Jana, 24 March, pp. 7-9.

Stark, R. and Finke, R. (2000) Acts of Faith: Explaining the Human Side of Religion (Los Angeles, University of California Press).

Szosztakewicz, A. (1999) 'Religion after communism', Commonweal, 126, p.16.

Štuhec, I. et al. (2002) Izberi življenje (Choose Life) (the final document of the Slovenian Catholic Synod) (Ljubljana, Družina).

Toš, N. et al. (1999) Podobe o cerkvi in religiji (Images of Church and Religion) (Ljubljana, Fakulteta za Družbene Vede).

Toš, N. (ed.) (1999) Vrednote v Prehodu (Values in Transition) II (Ljubljana, Fakulteta za Družbene Vede).

Žerdin, A. (1999) 'Dresura za nemške ovčarje' ('Training of German sheepdogs'), Mladina, 6, pp. 26-28. 